\title{
PELATIHAN PENGELASAN UNTUK ANAK-ANAK PANTI ASUHAN AKHLAQUL KARIMAH KOTA MALANG
}

\author{
Aladin Eko Purkuncoro*, Mochtar Asrori, Teguh Rahardjo \\ Fakultas Teknologi Industri Teknik Mesin ITN Malang \\ *Email: aladin_smart@yahoo.com \\ (Diterima 25-02-2020; Disetujui 23-03-2020)
}

\begin{abstract}
ABSTRAK
Keterampilan yang mandiri dapat dibina melalui pelatihan yang terus menerus secara periodik dengan pola pelaksanaan yang telah ditentukan oleh pemerintah berdasarkan tingkat kebutuhan masyarakat. Bagi industri kecil dan menengah di bidang permesinan dan konstruksi baja ringan, lingkup pekerjaannya tidak bisa lepas dari bahan logam (terutama baja). Hasil produk yang dihasilkan selalu berkaitan dengan penyambungan antar komponen logam, penyambungan antar komponen yang paling umum bisa dilakukan adalah dengan mur baut, keling maupun las. Dalam pengabdian masyarakat melalui pelatihan ini dapat memberikan informasi tentang tugas dan kewenangan pemeriksa pengelasan; memberikan pemahaman tentang dasar perhitungan kekuatan sambungan las, yang kemudian dipusatkan pada pembacaan tabel; memahami fenomena penyimpangan setelah proses pengelasan; memberikan pemahaman tentang cara memperbaiki cacat pengelasan. Juga dalam pelatihan ini bisa mendapatkan proses pengelasan dengan menggunakan prosedur pengelasan, sehingga manajemen proses pengelasan bisa berjalan dengan baik; mereduksi tingkat kegagalan pengelasan, sehingga penggunaan bahan lebih efektif, dan meningkatkan mutu sambungan las.
\end{abstract}

Kata kunci: Pelatihan, Pengelasan, Proses Pengelasan

\section{PENDAHULUAN}

Anak asuh panti asuhan Akhlaqul Karimah merupakan sumber daya manusia yang perlu diberikan pembekalan ketrampilan disamping ilmu yang diperoleh melalui pondoknya sendiri. Keterampilan yang mandiri dapat dibina melalui pelatihan yang terus menerus secara periodik dengan pola pelaksanaan yang telah ditentukan oleh pemerintah berdasarkan tingkat kebutuhan masyarakat.

Bagi industri kecil dan menengah di bidang permesinan dan konstruksi baja ringan, lingkup pekerjaannya tidak bisa lepas dari bahan logam (terutama baja). Hasil produk yang dihasilkan selalu berkaitan dengan penyambungan antar komponen logam, penyambungan antar komponen yang paling umum bisa dilakukan adalah dengan mur baut, keling maupun las.

Sambungan dengan pengelasan, merupakan sambungan antar komponen yang praktis dan menghasilkan sambungan yang lebih ringan (dibanding mur-baut dan keling). Namun kegagalan pengelasan sering dijumpai karena logam yang dilas tidak sesuai dengan elektroda yang digunakan, dan menyebabkan menurunnya kekuatan sambungan. Karena penanganan pekerjaan pengelasan harus dilakukan secara khusus (seperti: welding procedure dan operator yang bersertifikat), maka pengelasan menjadi pekerjaan yang sangat penting dan melibatkan lembaga sertifikasi. 
Suatu upaya peningkatan ketrampilan SDM anak asuh panti asuhan Akhlaqul Karimah adalah melalui pelatihan tentang pengelasan, dimana nantinya diharapkan dapat tercipta berdirinya suatu bengkel pengelasan yang dikelola oleh anak asuh panti asuhan Akhlaqul Karimah secara mandiri.

Evaluasi terhadap hasil pelatihan dilaksanakan untuk mengetahui sampai sejauh mana serapan materi pelatihan yang diperoleh peserta, yang tercermin dari sikap trampil yang dimiliki oleh peserta pelatihan. Adapun proses evaluasinya dilaksanakan dengan cara melakukan test akhir pelatihan, yang terdiri atas: test teori dan test praktek.

Pelatihan ini bisa dirancang sedemikian rupa sehingga mudah dipahami oleh para peserta yang umumnya adalah operator yang tidak mempunyai sertifikat. Oleh karena banyaknya operator las yang tidak mempunyai sertifikat ini, diharapkan bisa mengikuti bahan pelatihan dengan mudah dan tidak merasa kesulitan.

Dalam pengabdian masyarakat melalui pelatihan ini dapat memberikan informasi tentang tugas dan kewenangan pemeriksa pengelasan. Memberikan pemahaman tentang dasar perhitungan kekuatan sambungan las, yang kemudian dipusatkan pada pembacaan tabel. Memahami fenomena penyimpangan setelah proses pengelasan. Memberikan pemahaman tentang cara memperbaiki cacat pengelasan. Juga dalam pelatihan ini bisa mendapatkan proses pengelasan dengan menggunakan prosedur pengelasan, sehingga manajemen proses pengelasan bisa berjalan dengan baik. Mereduksi tingkat kegagalan pengelasan, sehingga penggunaan bahan lebih efektif. Meningkatkan mutu sambungan las.

\section{BAHAN DAN METODE}

Pretest.

Tatap muka dan diskusi kelas, Experience sharing, serta bedah kasus yang dihadapi peserta latih di lapangan.

\section{Post test.}

1. Metode yang akan diterapkan terdiri atas pembuatan beberapa jobsheet produk komposit hybrid dan pelatihan cara dan penggunaan, serta pembuatan produk dengan proses pengelasan dengan hasil yang bagus.

2. Pelaksanaan pengabdian masyarakat mulai dai survey, studi literatur sampai pembuatan beberapa produk dari bahan lain untuk lebih mempunyai pengalaman dalam proses pembuatan bahan produk seperti diagram alir proses pengabdian. 
Di dalam bengkel las terdapat dua buah botol dengan warna yang berbeda, botol warna biru untuk asam $\left(\mathrm{O}_{2}\right)$ dan warna merah batu bata untuk gas Asetilin $\left(\mathrm{C}_{2} \mathrm{H}_{2}\right)$. Adapun selang biru atau hijau untuk zat asam dan untuk warna merah untuk zat asetilin.

Ciri-ciri khas manometer untuk zat asam adalah menggunakan Ulir kanan sedang untuk gas asetilin menggunakan Ulir kiri.

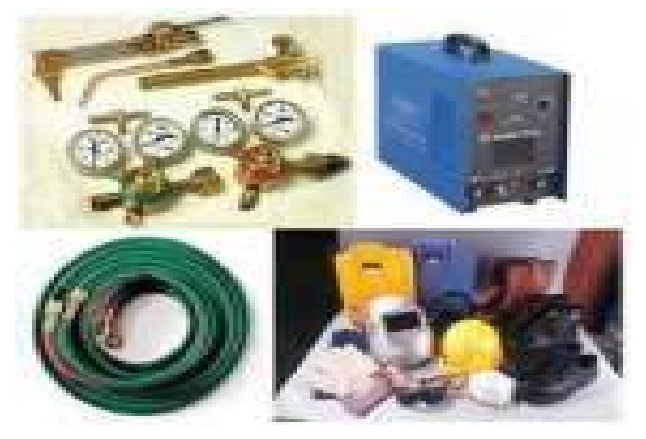

Gambar 1. Perlengkapan las

\section{Tabung zat asam}

Zat asam atau oksigen $\left(\mathrm{O}_{2}\right)$ adalah gas yang sangat penting untuk pembakaran. Zat asam lebih berat dari udara, tidak berbau dan tidak berwarna. Zat asam dapat tersimpan dengan aman di dalam silinder dengan tekanan 150 bar. Di dalam udara terdapat $21 \%$ zat asam, untuk mengetahui isi tabung, seandainya diketahui 501 zat asam cair dengan tekanan 150 bar, maka dihitung zat asam berupa gas 50 × $150=75001$. Warna tabung di dalam perdagangan adalah biru, hijau dan abu-abu.

Katup tabung dibuat dari bahan kuningan dan dilengkapi dengan kepingan pengaman yang akan pecah bila terjadi kenaikan tekanan di dalam tabung. Kenaikan tekanan dapat terjadi apabila tabung jatuh atau terkena panas.

Apabila tabung tidak dipakai tutuplah tabung tersebut dengan tutup baja yang sesuai. Kerusakan pada katup dapat menimbulkan bahaya yang besar, apabila katup pecah Zat asam akan menyembur ke luar dan tabung dapat terbang seperti roket.

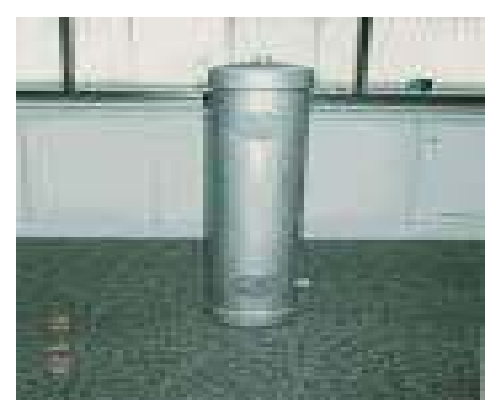

Gambar 2. Botol zat asam 


\section{Tabung zat asetilin}

Diisi dengan bahan berpori seperti kapas, sutra tiruan atau asbes yang berfungsi sebagai penyerap aseton. Aseton adalah bahan dimana asetilin dapat larut dengan baik dan aman di bawah pengaruh tekanan. Isi bahan berpori pada tabung $=25 \%$ dan dapat menyerap aseton sebanyak $=40 \%$ dari isi tabung. Tiap 1 liter aseton pada tekanan 15 bar dapat menampung gas asetilin sebanyak $40 \times 360 \times 0,4=5.760$ liter.

Perlu diketahui dan diingat bahwa tabung akan bertambah panas setiap gas asetilin keluar dari tabung, maka dari itu jangan memakai gas asetilin lebih dari 750 liter/jam agar tabung tidak panas dan aseton tidak terserap.

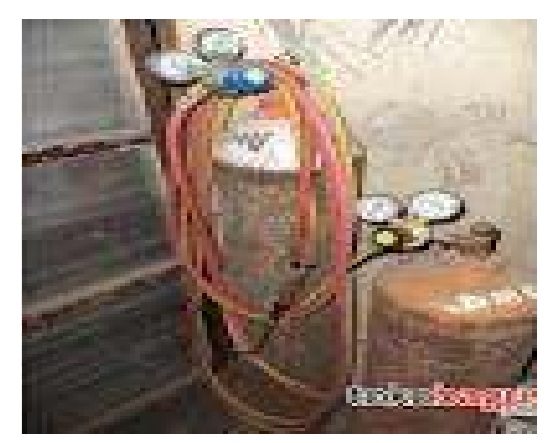

\section{Gambar 3. Botol zat asetilin}

\section{Selang}

Dipergunakan untuk pengelasan dapat dikenal dengan mudah, warna biru atau hijau untuk gas asam dan warna merah untuk gas asetilin. Panjang selang minimal $5 \mathrm{~m}$, dengan menggunakan klem ganda. Mengikat kedua selang dengan jarak satu dengan yang lain $1 \mathrm{~m}$, sehingga dalam melakukan pekerjaan terlihat rapi dan aman.

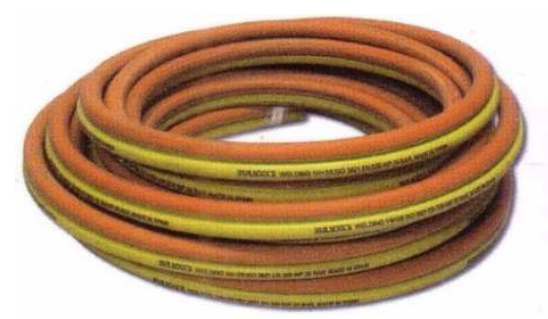

Gambar 4. Selang 


\section{Tempat kerja}

Terdiri atas meja yang permukaan sebagai dari batu tahan api dan bagian lain dari besi siku posisi tengkurap. Di sebelah depan terletak tempat air untuk pendingin ujung pembakar, sebelah kiri terletak tempat bahan tambah, tiang untuk penjepit benda kerja dan di sebelah kanan terletak tempat untuk meletakkan/menggantung pembakar.

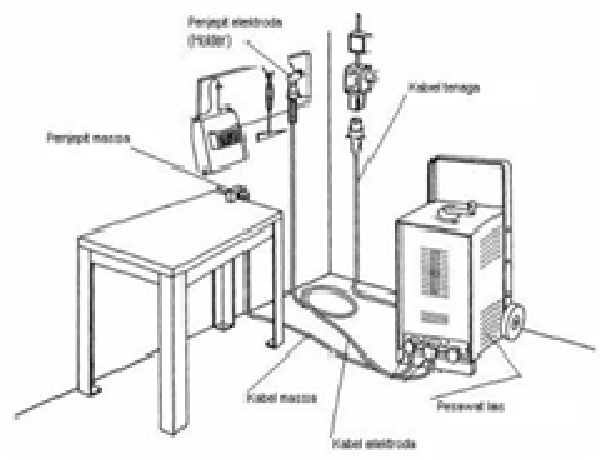

Gambar 5. Meja las

\section{Pakaian kerja}

Di dalam pekerjaan las gas diperlukan pakaian kerja yang dilindungi dari api dengan pelindung dari kelit (Apron). Adapun guna dari pelindung yang terbuat dari kulit yaitu tidak akan menembus ke pakaian dan ke badan karena percikan-percikan api dari ujung pembakar. Serta jangan lupa menggunakan pelindung untuk sepatu, karena kalau percikan sampai masuk ke dalam sepatu, maka akan dibuat sesuatu olehnya dan akan mengurangi konsentrasi dalam pekerjaan.

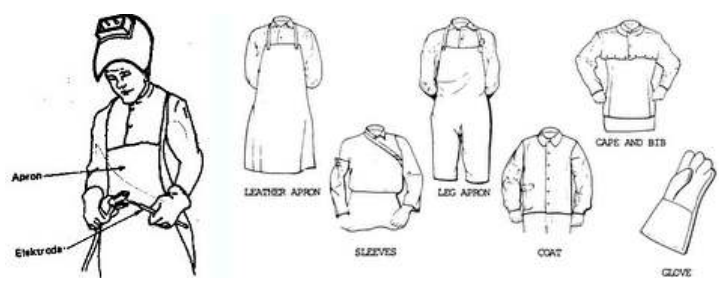

Gambar 6. Pakaian Las

6. Topi

Untuk melindungi kepala/rambut dari percikan-percikan api adapun kaca mata untuk melindungi mata dari percikan-percikan api, sinar yang menyilaukan dari ujung pembakar dan untuk mengurangi panasnya api terhadap mata. 


\section{HASIL DAN PEMBAHASAN}

Bagi kampus Institut Teknologi Nasional Malang, kegiatan ini merupakan wujud nyata partisipasi dunia pendidikan dalam pengabdian kepada masyarakat melalui pendidikan dan pelatihan maupun penerapan teknologi sehingga masyarakat dapat memanfaatkannya dalam menjalankan usahanya.

Pelatihan ini dapat memberikan informasi tentang pemahaman tentang dasar perhitungan kekuatan sambungan las, memahami fenomena penyimpangan setelah proses pengelasan serta dapat memberikan pemahaman tentang cara memperbaiki cacat pengelasan. Pelatihan ini dirancang sedemikian rupa sehingga mudah dipahami oleh anak-anak yang diharapkan bisa mengikuti bahan pelatihan dengan mudah dan tidak merasa kesulitan.

Proses pengelasan ini juga terdapat beberapa metode yang berbeda, yaitu: (1) Pengelasan dengan cara menggunakan energi listrik, yaitu dengan cara melelehkan dua potong logam secara bersamaan serta menambahkan logam pengisi (filler) di antara sendisendi kedua logam tersebut sehingga keduanya akan saling mengikat satu sama lain, (2) Pengelasan dengan menggunakan gas bertekanan sebagai bahan bakar untuk melelehkan dua logam tersebut, dan (3) Pengelasan dengan cara mengombinasikan cara pertama dengan cara kedua, yaitu kombinasi antara listrik dengan gas bertekanan.

Setelah mengikuti kegiatan ini, anak-anak panti asuhan mampu membuat produk usaha mandiri yang memiliki kualitas unggul dimana semua anggotanya juga memiliki semangat yang tinggi dalam berkarya.

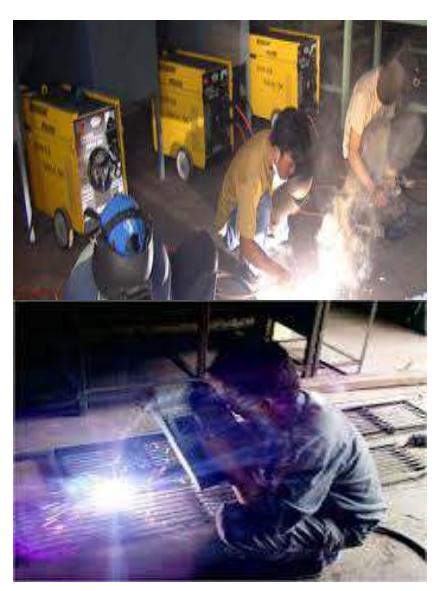

Gambar 7. Sketsa Gambar Pelatihan Pengelasan 


\section{KESIMPULAN DAN SARAN}

\section{Kesimpulan}

Pelatihan ini dirancang sedemikian rupa sehingga mudah dipahami oleh anak-anak Panti Asuhan Akhlakul Karimah yang diharapkan bisa mengikuti bahan pelatihan dengan mudah dan tidak merasa kesulitan.

1. Meningkatkan wawasan/ilmu terhadap anak-anak Panti Asuhan Akhlakul Karimah tentang proses pengelasan.

2. Dapat terciptanya usaha mandiri oleh anak-anak Panti Asuhan Akhlakul Karimah.

\section{Saran}

Hendaknya pelatihan ini dilakukan dengan terstruktur agar anak-anak Panti Asuhan Akhlakul Karimah diharapkan dapat menghasilkan produk dengan lebih baik tanpa adanya hambatan.

\section{DAFTAR PUSTAKA}

Angus, H.T. 1976. Cash Iron; Physical And Enggineering Propertis, Scond Edition, Butterworts, London.

Birch, N.A. 1953. Principle Of metal Casting, A Talk Given Before Wisconsin Chapter AFS.

Chijiwa, K., Sudira, T. 1980. Teknik Pengecoran Logam, Cetakan ketiga. Jakarta: PT Pradnya Paramita.

Fatchurahman, A. 2011. Pengelasan Oksi Asetilin, Academia.

Heine, R.W., Lopes, C.R. and Rosenthal, P.C., 1986. Principles of Metal Castings, TMH Edition, Tata Mc Graw Hill Publishing Co, Pany Ltd., New Delhi.

International Student Edition, Mc Graw-Hill Book Co, Singapore, 1986.

Metals Hand Book, Atlas Of Microstructures of Industrial Alloys, $8^{\text {th }}$ edition, vol 7, American Society For Metals, Metals Park, Ohio.

Saito, S. dan Surdia, T. 1984. Pengetahuan Bahan Teknik. Jakarta: PT. Pradnya Paramita.

Shaury, A. 2017. Makalah Teknik Las Tabung Gas Oksigen dan Asitelin.

Undang-Undang No 4 Tahun 1979 tentang Kesejahteraan Anak.

Wiryosumarto, H. dan Okumura, T. 2000. Teknologi Pengelasan Logam. Jakarta: Pradnya Paramita. 